\title{
Analysis of Raft \& Pile Raft Foundation using Safe Software
}

\author{
Sunesra Shakir ${ }^{\mathrm{a}}$, Shaikh Mudassir ${ }^{\mathrm{a}}$, Shaikh Abdullah ${ }^{\mathrm{a}}$, Qureshi Najesh ${ }^{\mathrm{a}}$, Majead Pathan ${ }^{\mathrm{b}}$, \\ Sunasra Sufyan ${ }^{\mathrm{c}}$,Owais Kharodia ${ }^{\mathrm{d}}$, \\ * a Student Department of Civil Engineering, Rizvi College of Engineering, Mumbai, Maharashtra, India. \\ * b Asst-Professor, Department of Civil Engineering, Rizvi College of Engineering, Mumbai, Maharashtra, India. \\ * c Structural design engineer, Hanware Structural Consultants, Mumbai, Maharashtra, India. \\ * d Structural design engineer, Frames Structural Consultants, Mumbai, Maharashtra, India.
}

\begin{abstract}
The proposed Project Analysis of Raft and Piled raft foundation is based on analyzing of the residential building structure using commercially adopted structural software "SAFE-12.3.2". This project comprises of G+22 storeys residential building located in Noida, Delhi. Raft foundations is the favorite choice for most of the designers but now days due to constraints of cost increment, decreasing availability of land because of rapid industrialization \& urbanization there is growth in vertical direction resulting in many high rise building coming up. This has resulted in heavy load, complicated stress conditions and limitation of bearing capacity of soil. This results in settlement of high rise buildings. As a solution to the settlement problem of high rise buildings number of piles are used and new type of foundation called as combined piled raft foundation is coming up in a big way. Combined piled raft foundation is an efficient foundation for medium rise buildings in which the superimposed load is transferred to the soil by the combined action of pile and raft and facilitates settlement reduction. Raft and pile are combined in a view to reduce the overall settlement of the structure. The aim of this project was to reduced the Settlement and Soil bearing pressure within the permissible limit as per given in IS CODE 1904:1986.
\end{abstract}

Keywords:- Settlement, soil bearing pressure, superimposed load ,stresses, Piles with Raft foundation.

\section{INTRODUCTION}

Foundations provide support to superstructures; which transfer their load to layer of soil or rock that have a sufficient bearing capacity. Generally pile foundation or raft foundation are used

Whereas Combined pile raft foundation is a hybrid type of foundation, in which some amount of load is taken by pile and other by raft. Raft foundation transfer the load coming from super structure to the soil in the form of continues slab it's generally provided when the total area covered by the column is greater than $75 \%$. Pile is cylindrical strong material made up of concrete and steel which transfer the load coming from superstructure directly to hard strata which is located definite level below the ground surface Pile raft foundation is design in such a manner that ultimate loading of structure is taken by raft foundation; as the ultimate loading is taken by raft the differential settlement in the raft increases the permissible value to reduce the differential settlement pile are embedded in raft foundation. Hence in combined pile raft foundation the ultimate load of the structure is taken by raft foundation and settlement is reduced by pile foundation. Also combination of the shallow foundation and deep foundation can be a cost effective design approach.

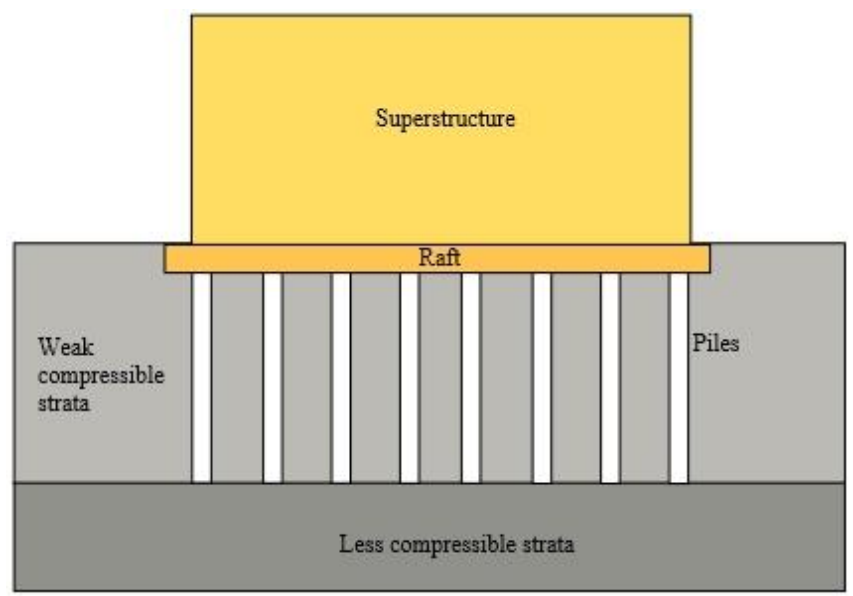

Fig 01: Piles with raft foundation

\section{PROBLEM STATEMENT}

Why Piled Raft foundation over Raft foundation?

In the normal form, raft foundation is shallow foundations formed by a reinforced concrete slab of uniform thickness (typically 150-300 $\mathrm{mm}$ ) covering a wide area, often the entire footprint of a building. This 'raft' spreads the load imposed by a number of columns or walls over the area of foundation,

It distributes the weight of the building over the entire area of the building, and not over smaller zones (like individual footings) or at individual points (like pile foundations). This reduces the stress on the soil. But in case if we construct a high rise building in sandy soil then differential settlement occurred. Which leads to crack in the raft foundation and ultimately the foundation fail.

However, where a conventional raft foundation does not provide adequate support, it can be enhanced by the addition of piles, creating a piled raft foundation. The addition of piles to a raft increases the effective size of a foundation. This can

Improve the performance of the foundation in reducing the amount of settlement and differential settlement, as well as 
improving the ultimate load capacity. Piled raft foundations are typically used for large structures and in situations where soil is not suitable to prevent excessive settlement. During the design process, the optimum number and position of piles, as well as their diameter, reinforcement and length, is determined by knowing the settlement at different locations . Typically, the piles provide most of the stiffness (hence only friction piles are used) while the raft provides additional capacity at the ultimate loading. If there are one or more ineffective piles, the raft can allow some degree of load redistribution to other piles, reducing the influence of the pile's weakness on the overall performance of the foundation.

\section{SCOPE AND OBJECTIVE}

\section{SCOPE:}

a) Using pile raft foundation,tall buildings can be constructed in small plot area.

b) To make the foundation more effective and economical with using pile along with raft.

c) Piles of different diameter with different sizes are considerably used to reduce the total and differential settlement.

d) Different arrangements of piles along with raft(as per the soil condition)can be used in order to get the best combination of less pile with high bearing capacity and ultimately reduces the costing of piling,hence economical.

\section{OBJECTIVE:}

a) The behavior of the piled raft foundation can be analysed for the increments in the pressure load on the raft.

b) Effect of coefficient of subgrade reaction of soil and pile stiffness on the settlement and bending moment of raft are studied.

c) To reduce the total and differential settlements of Foundation.

d) To evaluate the engineering properties of soil.

e) To study the effect on displacements of raft with the introduction of piles.

\section{LITERATURE REVIEW}

a) $\quad$ R.R Chaudhary, Dr K. N. Kadam. Effect of Piled Raft Design on High-Rise Building Considering Soil Structure Interaction. :- R. R. Chaudhary, Dr K. N. Kadam Piled-raft foundations for important high-rise buildings have proved to be a valuable alternative to conventional pile foundations or mat foundations. The concept of using piled raft foundation is that the combined foundation is able to support the applied axial loading with an appropriate factor of safety and that the settlement of the combined foundation at working load is tolerable. Pile raft foundation behavior is evaluated with many researches and the effect of pile length; pile distance, pile arrangement and cap thickness are determined under vertical or horizontal static and dynamic loading. In the present paper the influence of pile length configurations on behavior of mufti-storied are evaluated under vertical loading. In practice, the foundation loads from structural analysis are obtained without allowance for soil settlements and the foundation settlements are estimated assuming a perfectly flexible structure. However, the stiffness of the structure can restrain the displacements of the foundations and even tiny differential settlements of the foundations will also alter forces of the structural members. Hence, the interaction among structures, their foundations and the soil medium below the foundations alter the actual behaviour of the structure.

b) Anuj Chandiwala. Fem Modelling For Piled Raft Foundation in Sand Anuj Chandiwala. In recent years, there have been an increasing number of structures using piled rafts as the foundation to reduce the overall and differential settlements. For cases where a piled raft is subjected to a non-uniform loading, the use of piles with different sizes can improve the performance of the foundation. Extensive research work has been performed in the past to examine the behaviour of piled rafts. However, most of the research was focused on piled rafts supported by identical piles, and the use of non-identical piles has not received much attention. In this paper, the behaviour of piled raft is examined by the use of a computer program 18 MIDAS GTS based on the finite layer and finite element methods. The finite layer method is used for the analysis of the layered soil system. The finite element method is used for the analysis of the raft and piles. Full interaction between raft, piles and so il which is of major importance in the behaviour of piled rafts is considered in the analysis. Among the four different types of interaction present in the piled raft foundation. The interaction between piles plays an important role. Two dimensional (2D) finite element analyses of un-piled and piled raft foundations with sandy soil. For the un-piled raft, the normalized settlement parameter (IR) for the raft sizes of $8 \mathrm{mx} 8 \mathrm{~m}$ and $15 \mathrm{mx} 15 \mathrm{~m}$ ranged as $1.03-1.17 \mathrm{~mm}$ and $0.66-0.83 \mathrm{~mm}$ respectively. In the case of the piled raft with raft thickness of $0.25,0.40$, $0.80,1.50,3.0 \mathrm{~m}$, the corresponding maximum settlements are $66,64,63.7,63 \mathrm{~mm}$. The results of these analyses are summarized into a series of design charts, which can be used in engineering practice.

c) Poulos, H. G. (2001). "Piled Raft Foundations: Design and Applications" H.G.Poulos. This paper describes the philosophy of using piles as settlement reducers and the condition under which such an approach may be useful. Some of the characteristics of Piled raft behaviour are also described. The design process of Piled raft is explained in three stages. The first is preliminary stage in which the effect of number of piles on the capacity and the settlement are assessed via an approximate analysis. The second is a more detail study to asses to find out where piles are required. The third is detailed design phase in which a more refined analysis is employed to confirm optimum number and locations of piles. 
d) S.J. Shukla, Dr.A.K.Desai, Dr. C.H.Solanki reported that the use of piled raft foundations has become more popular in recent years, as the combined action of the raft and the piles can increase the bearing capacity, reduce settlement, and the piles 20 can be arranged so as to reduce differential deflection in the raft. Piled raft foundation is a new concept in which the total load coming from the superstructure is partly shared by the raft through contact with soil and the remaining load is shared by piles through skin friction. A piled raft foundation is economical compared to the pile foundation. Because piles do not have to penetrate the full depth of clay layer but it can be terminated at higher elevations. Such piled raft foundation undergoes more settlement than the pile foundation and less settlement than the raft foundation. In this paper the author has study different parameters like size of the raft, thickness of the raft, diameter of the piles, length of piles, configuration of piles stiffness of raft and piles etc., which affect the behaviour of piled raft foundation. And its interdependency is also reviewed. This study is useful to decide the various parameters required in the design of piled raft foundation. From the literature review it has been studied that In comparison to shallow (raft) foundations, piled rafts reduce effectively the settlements, the differential settlements and the bending moment proportionally in tall buildings. To reduce the differential settlement and moment the piles should be place strategically using some trial and error or using parametric study. In more the soil structure interaction of piled raft.

\section{METHOD OF MODELLING AND ANALYSIS}

To examine the behavior of piled raft foundation ETABS 2016 and SAFE-12.3.2 is used. First Investigation of the site location is done where the bearing capacity of soil is poor and taking the SBC of soil in that area and basic tests are carried out to study the properties of the soil. Using ETABS software the 22 storey building is analyzed then by importing the super structural loads using the SAFE software the raft foundation is modeled and analyzed but as the settlement and SBC was not within the permissible limits we have introduced piled raft foundation and finally Optimum combination of pile and raft dimensions is selected. Here piles are assigned as pile spring value by calculating the spring value that is $\mathrm{K}$ and assigned in SAFE-12.3.2 software .

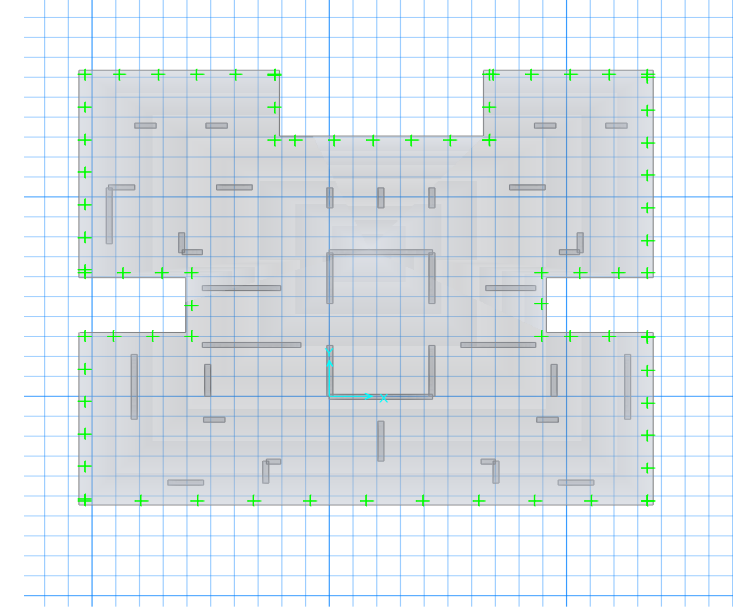

Fig 02: Finite element model.

\section{A) SECTION PROPERTIES}

Table 1: Slab Properties

\begin{tabular}{cccrc}
\hline Slab & Type & MatProp & $\begin{array}{r}\text { Thickness } \\
\mathrm{mm}\end{array}$ & Ortho \\
\hline S1300M30 & Mat & M30 & 1300.000 & No \\
S1500M35 & Mat & M35 & 1500.000 & No
\end{tabular}

Table 2: Beam Properties

\begin{tabular}{ccrrr}
\hline Beam & MatProp & $\begin{array}{r}\text { Depth } \\
\mathrm{mm}\end{array}$ & $\begin{array}{r}\text { WidthTop } \\
\mathrm{mm}\end{array}$ & $\begin{array}{r}\text { WidthBot } \\
\mathrm{mm}\end{array}$ \\
\hline W350M40-W & MAT1 & 4200.000 & 350.000 & 350.000 \\
\hline
\end{tabular}

Table 3: Wall Properties

\begin{tabular}{lcrcc} 
Wall & MatProp & $\begin{array}{r}\text { Thickness } \\
\text { mm }\end{array}$ & AutoRigid & \\
\hline W300 & C30 & 300.000 & No & Yes \\
\hline
\end{tabular}

B) MATERIAL PROPERTIES

Table 1: Material Properties Concrete

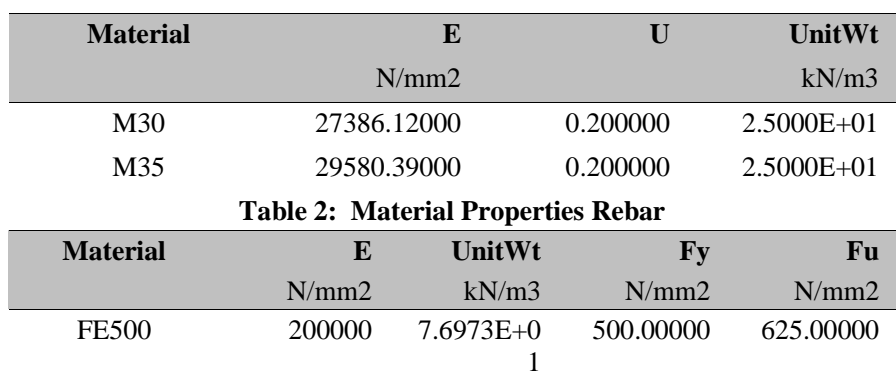

C) SUPPORT PROPERTIES

Table 1: Soil Properties

\begin{tabular}{cr} 
Soil & $\begin{array}{r}\text { Subgrade } \\
\mathrm{kN} / \mathrm{m} 3\end{array}$ \\
\hline Raft Subgrade reaction & $4.0000 \mathrm{E}+03$
\end{tabular}




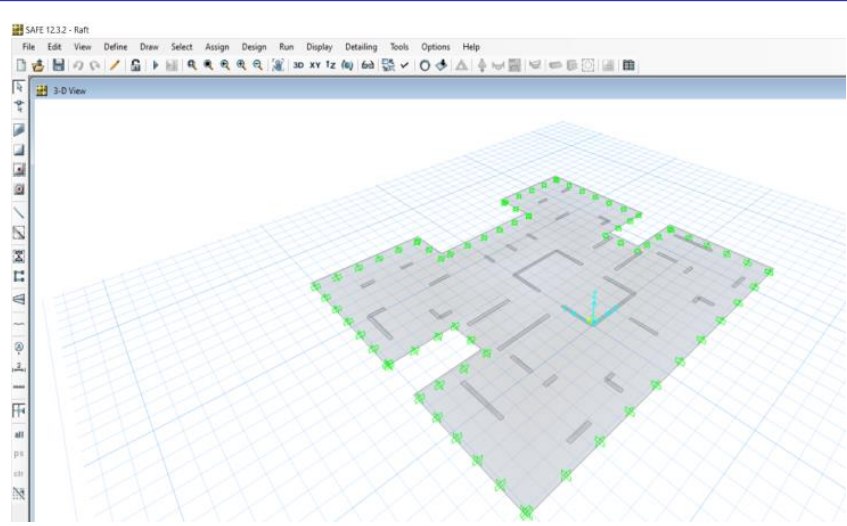

Fig 03: Assignment of soil subgrade modulus.

Modulus of subgrade reaction $(\mathrm{k})$, $\mathrm{k}=\mathrm{SBC} /$ settlement $\left(\mathrm{KN} / \mathrm{m}^{2}\right)$

\section{D) MODEL GEOMETRY}

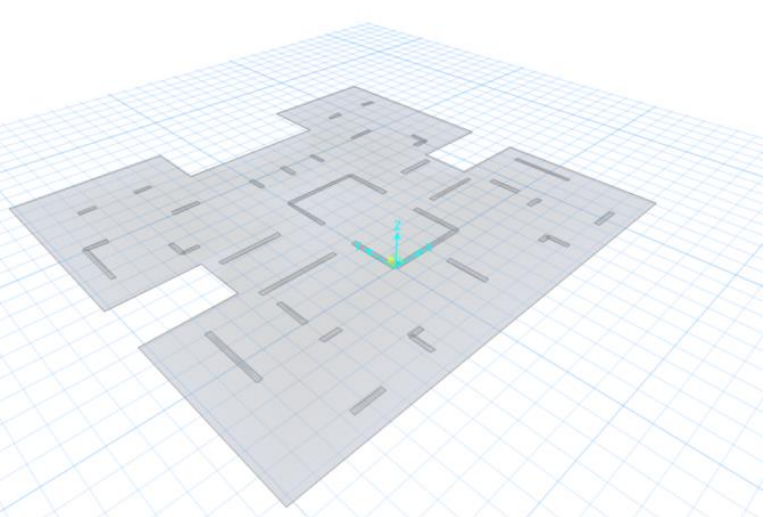

Fig 04: Raft foundation 3D view.

Fig 05: Pile Raft foundation 3D view.

\section{E) MODEL LOADING}

This section provides model loading information, including load patterns, load cases, and load combinations.

\begin{tabular}{ccc}
\multicolumn{3}{c}{ Table 01: Load Patterns } \\
\hline LoadPat & Type & SelfWtMult \\
\hline DEAD & DEAD & 1.000000 \\
LIVE & LIVE & 0.000000 \\
FF & SUPER DEAD & 0.000000 \\
SUNK & SUPER DEAD & 0.000000 \\
WALL & SUPER DEAD & 0.000000
\end{tabular}

Table 02: Load Cases Linear - Static

\begin{tabular}{ccc}
\hline LoadCase & InitialCond & AType \\
& & \\
\hline DEAD & Zero & Linear \\
LIVE & Zero & Linear \\
FF & Zero & Linear \\
SUNK & Zero & Linear \\
WALL & Zero & Linear
\end{tabular}

Table 03: Load Combinations

\begin{tabular}{cccc}
\hline Combo & Load & SF & Type \\
& & & \\
\hline DL+LL & DEAD & 1.000000 & Linear Add \\
DL+LL & LIVE & 1.000000 & \\
DL+LL & FF & 1.000000 & \\
DL+LL & SUNK & 1.000000 & \\
DCON1 & DEAD & 1.500000 & Linear Add \\
DCON1 & FF & 1.500000 & \\
DCON1 & SUNK & 1.500000 & \\
DCON2 & DEAD & 1.500000 & Linear Add \\
DCON2 & LIVE & 1.500000 & \\
DCON2 & FF & 1.500000 & \\
DCON2 & SUNK & 1.500000 &
\end{tabular}

\section{RESULTS AND DISCUSSIONS}

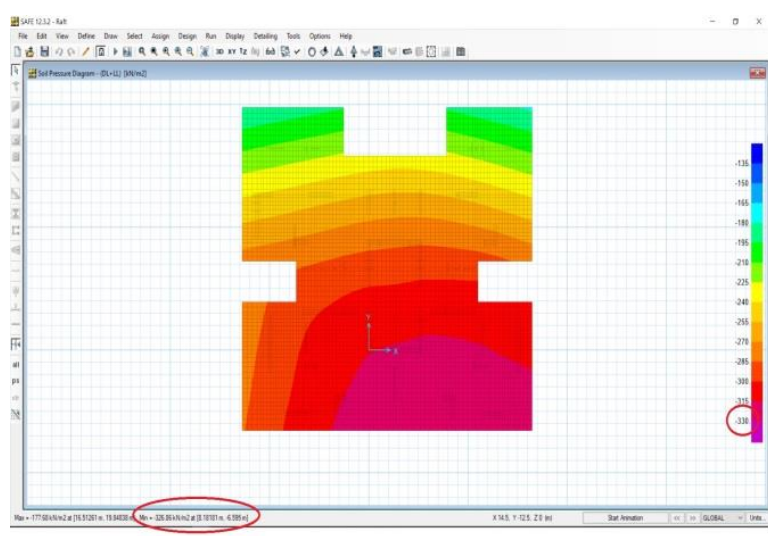

Fig 06: Raft foundation soil pressure reaction.

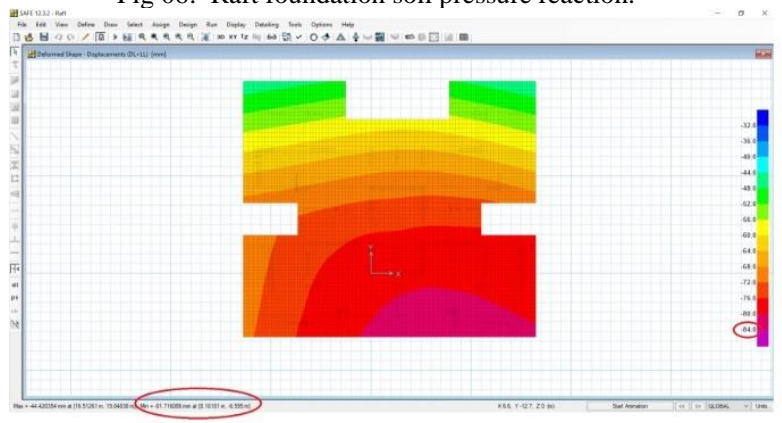

Fig 07: Raft foundation settlement 
As per the analysis of the soil report the soil permissible settlement of the foundation is $50 \mathrm{~mm}$ for service condition. Actual settlement of raft is much more than the permissible limit. Hence it is necessary to provide piles below the raft to reduce the settlement. To control the settlement of the raft, pile foundation is introducing below the raft at $28 \mathrm{~m}$ depth and to know the behavior of piles and raft the parameters of the piles and raft are varied depending upon the parameter the optimum one is verified.

Diameter of pile $=600 \mathrm{~mm}$

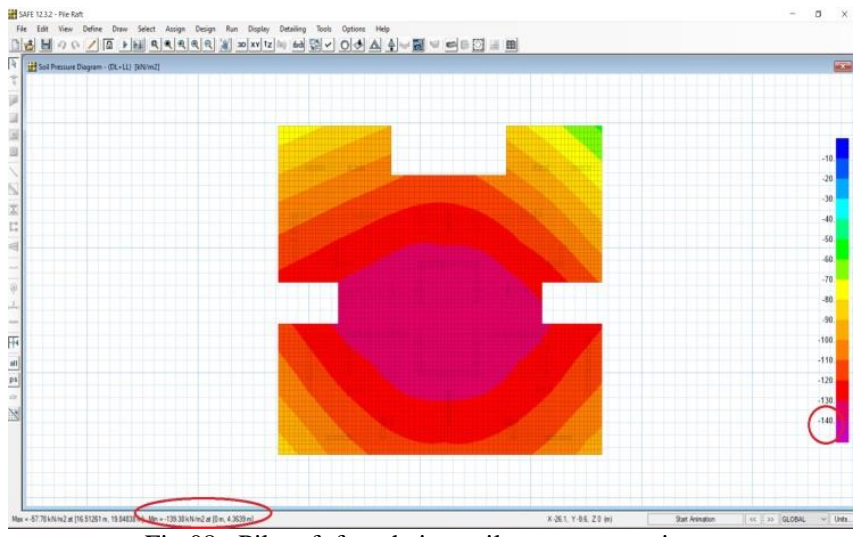

Fig 08: Pile raft foundation soil pressure reaction.

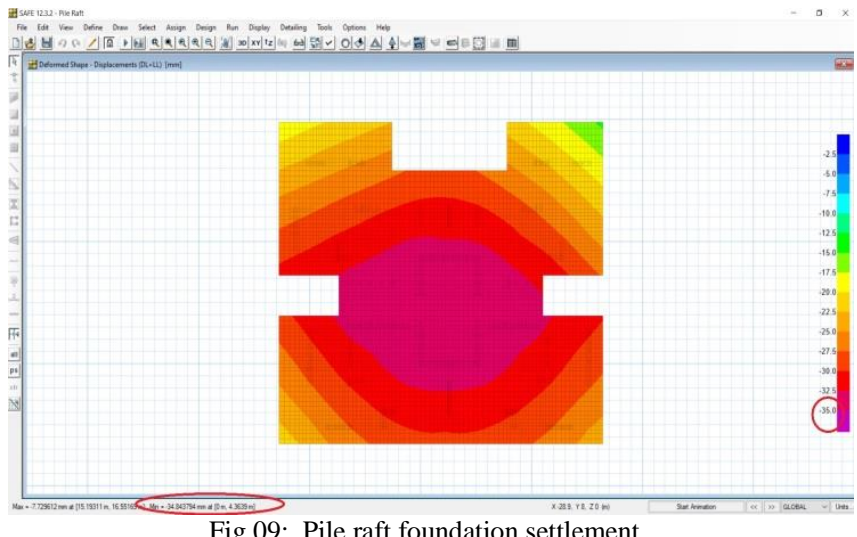

Fig 09: Pile raft foundation settlement

\begin{tabular}{|l|l|l|}
\hline & Raft foundation & Pile raft foundation \\
\hline Settlement & $81.71 \mathrm{~mm}$ & $35 \mathrm{~mm}$ \\
\hline SBC of soil & $327 \mathrm{KN} / \mathrm{m}^{2}$ & $140 \mathrm{KN} / \mathrm{m}^{2}$ \\
\hline
\end{tabular}

Permissible limits:

1) Settlement :-50 $\mathrm{mm}$ for service condition as per IS Code 456:2000.

2) SBC of soil:-200KN/m2 as per Geo-technical Report provided.

\section{CONCLUSION}

Pile with Raft foundation is economical when compared to a single pile foundation or Raft foundation. In the present work piled with raft foundation, the load sharing of pile and raft results in gradual reduction of soil settlement when the piles are introduced below the raft.

By analyzing multi-storey residential building foundation Using SAFE software we conclude that:
- Analysis done by SAFE (ver.13.3.2) is very efficient and user friendly.

- Software is developed for the analysis of raft using finite difference method, estimation of stiffness for soil and pile.

- Piled raft foundation is adopted to reduce the total and differential settlement of foundations, and thus estimation of settlement profile of piled raft foundation forms an important design exercise.

- $\quad$ Piles are introduced at $6 \mathrm{~m}$ spacing as minimum spacing is $2.5 \mathrm{~m}$ but it would lead to pile action to avoid that Senior recommended to introduce pile at $6 \mathrm{~m}$ as per grid and we assured that pile comes below the column.

- We have reduced the Settlement and Soil bearing pressure within the permissible limit as per given in IS CODE 1904:1986 and Geo- technical report respectively.

\section{ACKNOWLEDGEMENT}

First of all we are thankful to respected principal Dr.Varsha Shah, Of RCOE, Mumbai and Prof.Avinash More (head of department) of Civil Branch for giving us a kind of approval to prepare and submit the project.

We also thank Prof. Majead Pathan for their guidance and continuous encouragement throughout the academic to see that this project rights to its target from its commencement to the completion.

We would also like to thank other relative professors and friends of civil department who really helped us in our project work.

We avail this opportunity to convey our sincere thanks to those who have directly or indirectly contributed to our project work and for the teaching us to see the silver lining in every Dark cloud.

\section{REFERENCES}

1. IS 456:2000, "Plain and Reinforced Concrete -Code of Practice", ISI New Delhi, 2000

2. IS 1893 part 1, "Criteria for Earthquake Resistant Design Of Structures, General Provisions and Buildings", BIS, New Delhi, 2002.

3. IS 2911 : PART 1 "Code of Practice for driven Cast in-Situ Concrete Piles"

4. Padmanaban M S, J Sreerambabu, "Issues on Design of Piled Raft foundation" Volume. 14 December 2017

5. Rahul Solanki, Sagar Sorte, "A Review of Piled Raft Foundation", ISSN 2278-3652 Volume 7, 2016

6. Dinachidinandra Thoidingjam, D S V Prasad, Dr. K.Rambha Devi, "Effect of Number of pile Raft system in organic clay" IOSR Volume 13 (Jul-Aug.2016).

7. Emilios M Comodromos, Mello C Papadopoulou and Ioannis K Rentzeperis (2009), "Pile Foundation Analysis and Design Using Experimental Data And 3-D Numerical Analysis", Science direct Computers and Geotechnics, Vol. 36 ,pp. 819-836.

8. Dang Dinh Chung Nguyen, Seong-Bae Jo and Dong-Soo Kim (2013), "Design Method of Piled-Raft Foundations under Vertical Load Considering Interaction Effects", Science direct- Computers and Geotechnics, Vol. 47, pp. 16-27.

9. Poulos, H.G (2001) small, J.C,. \& Chow, H (2011) "Piled Raft Foundation for Tall Buildings", 42(June), 78-84.

10. Solanki CH, Vasanvala SA, Patil JD. A study of piled raft foundation: state of art. Int J Eng Res Technol (IJERT) 2013;2(8);1464-70 